\title{
Comparative Study on the Chemical Composition and Amino Acid Profile of Periwinkle and Rock Snail Meat Powders
}

\author{
Ufot Evanson Inyang*, Idorenyin Gabriel Etim, Barthlomew Nyong Effiong \\ Department of Food Science and Technology, Faculty of Agriculture, University of Uyo, Uyo, Nigeria
}

Email address:

inyang.ufot@yahoo.com (U. E. Inyang)

${ }^{*}$ Corresponding author

\section{To cite this article:}

Ufot Evanson Inyang, Idorenyin Gabriel Etim, Barthlomew Nyong Effiong. Comparative Study on the Chemical Composition and Amino Acid Profile of Periwinkle and Rock Snail Meat Powders. International Journal of Food Science and Biotechnology.

Vol. 3, No. 2, 2018, pp. 54-59. doi: 10.11648/j.ijfsb.20180302.13

Received: March 30, 2018; Accepted: April 23, 2018; Published: May 21, 2018

\begin{abstract}
For the present study, edible parts (meat) from freshly harvested Tympanotonus fuscatus, Pachymelania aurita and Thais coronata were processed into powders and analyzed for proximate composition, amino acid profile and mineral content. The mean values obtained were compared with each other. Results showed that all the parameters determined varied among the three gastropod species. Powders prepared from the three species had high protein and low fat contents. The protein content ranged from $41.51 \%$ for $T$. fuscatus meat powder to $58.45 \%$ for $T$. coronata meat powder. The fat, ash, crude fibre and carbohydrate contents ranged from $2.94-3.19 \%, 10.26-13.85 \%, 0.38-0.46 \%$ and $25.13-36.17 \%$ respectively. The caloric value ranged from $358.71-371.82 \mathrm{kcal} / 100 \mathrm{~g}$. The total amino acid ranged from $77.76 \mathrm{~g} / 100 \mathrm{~g}$ protein for T. fuscatus meat powder to $83.53 \mathrm{~g} / 100 \mathrm{~g}$ protein for $T$. coronata meat powder while the total essential amino acid ranged from $32.97 \mathrm{~g} / 100 \mathrm{~g}$ protein for $T$. fuscatus meat powder to $37.77 \mathrm{~g} / 100 \mathrm{~g}$ protein for T. coronata meat powder. Majority of essential amino acid chemical scores were above $100 \%$ except for lysine that ranged from $80.00 \%$ to $97.24 \%$, tryptophan was $88.18 \%$ for T. fuscatus and $90.00 \%$ for P. aurita while threonine was $95.26 \%$ for T. coronata and $99.41 \%$ for T. fuscatus powder. The $\mathrm{Ca}, \mathrm{K}, \mathrm{Na}, \mathrm{Mg}, \mathrm{Fe}$ and $\mathrm{Zn}$ ranged from $41.38-79.02 \mathrm{mg} / 100 \mathrm{~g}, 29.51-42.10 \mathrm{mg} / 100 \mathrm{~g}, 68.24-81.16 \mathrm{mg} / 100 \mathrm{~g}, 140.00-208.05 \mathrm{mg} / 100 \mathrm{~g}, 9.05-11.62 \mathrm{mg} / 100 \mathrm{~g}$ and $2.64-3.08 \mathrm{mg} / 100 \mathrm{~g}$ respectively. The high protein and low level of the crude fibre contents in the meat powders will make them suitable for use in complementary foods. Also, the low fat content in the meat powders suggests that they could be incorporated in foods for hypertensive individuals and those that have fat related diseases. Successful application of these powders in food product formulation and product development will lead to increase utilization of these nutritious, cheap and readily available sources of meat protein.
\end{abstract}

Keywords: Tympanotonus fuscatus, Pachymelania aurita, Thais coronata, Meat Powder, Nutrient Composition

\section{Introduction}

Shellfish, fish and other aquatic organisms suitable for food are a rich source of biologically valuable protein [1]. Seafood is highly valued not only for its abundance of high quality protein, but also for the n-3 polyunsaturated fatty acids (PUFAs), and other nutrients, such as minerals, trace elements and vitamins [2]. These nutrients are essential for proper functioning of the body and are beneficial for growth, the brain and nervous system [3]. The protein quality of seafood is superior to those of meat and poultry [4]. They therefore play a significant role in human nutrition and health.
Periwinkle (Tympanotonus fuscatus and Pachymelania aurita) and Rock snail (Thais coronata) are gastropods of the phyllum mollusca. Molluscs are invertebrates that have their unsegmented soft bodies covered with calcareous shells [1]. Shellfish provide high quality protein with all the dietary essential amino acids for maintenance and growth of the human body [5]. The amount of fatty acid and the proportions of saturated, monounsaturated and polyunsaturated fatty acids in shellfish contribute to a healthful diet [6]. The nutrient composition of mollusc varies widely and depends on several factors including species, sex, maturity, seasonal conditions and feeding regime [7]. 
Gastropods are by far the largest group of molluscs and compose of about $80 \%$ of the phyllum [8]. The size, body and shell morphology as well as habitat of gastropods vary significantly from one species to another.

Periwinkles are shellfish found in the littoral region of the sea, brackish or estuarine water which are seasonal submerge regions like the mangrove swamps [9]. They crawl about under water but usually remain passive when left uncovered by the tide [10]. The two species of periwinkles commonly found in Niger Delta coastal region of Nigeria are Tympanotonus fuscatus and Pachymelania aurita [11]. Thais coronata (Rock snail) on the other hand is a species of sea snail, a marine gastropod mollusc in the family muricidae. They are easily found in the mangrove areas, sandy beaches and muddy sandy substrate areas [12].

Both periwinkle and Rock snail are commercially valuable shellfish in Akwa Ibom State, Nigeria. Their collection and marketing form an important economic activity among the people living along the coastal region. They constitute one of the relatively easily harvested shellfishes. The harvesting is usually by hand-picking. They are excellent sources of protein, good sources of minerals like calcium, potassium, iron and phosphorus and some vitamins [13, 14]. They are used in the preparation of indigenous traditional dishes such as "edikang ikong", "ekpang nkukwo", "afia efere" and "afang" soup among others by the Efik and Ibibio ethnic groups in Nigeria. They are consumed by both the rich and poor people. Many low income earners however depend on these shellfish meat as their major source of protein because of their cheapness and availability. The meat is considered good for cardiac disorder as it is free of cholesterol [4]. According to Ebong et al. [12], sub-chronic consumption of rock snail and periwinkle extracts by anaemic albino rats led to increase in red blood cell count, packed cell volume and haemoglobin concentration as well as differential white blood cell count and with no deleterious effect on the liver enzymes.

Even though periwinkle and rock snail are consumed on daily basis, our knowledge on the nutritive value is still fragmentary. Their short shelf-life coupled with the bulkiness caused by inedible shell limits their consumption to the coastal region where they are found. Also, lack of processing of these nutritious meats into form that could be used in food product formulation and development has hindered efficient utilization of the meat. The present study was aimed at processing periwinkle and rock snail meats into powders and comparing the nutrient composition of the powders.

\section{Materials and Methods}

\subsection{Material Procurement}

Freshly harvested periwinkles (Tympanotonus fuscatus and Pachymelania aurita) were obtained from Oron market while Rock snail (Thais coronata) was obtained from Itu creek, both in Akwa Ibom State, Nigeria.

\subsection{Preparation of Periwinkle and Rock Snail Meat into Powder}

For each of the samples, the whole body was thoroughly washed with potable water to remove mud and other adhered materials. Each sample was put in a stainless pot and boiled in water for $5 \mathrm{~min}$ at $100^{\circ} \mathrm{C}$, drained and allowed to cool to ambient temperature $\left(27 \pm 2^{\circ} \mathrm{C}\right)$. The edible portion (meat) was manually removed from the shell with the aid of a stainless pin. The shells were discarded while the meats were washed in potable water, drained, dried at $60^{\circ} \mathrm{C}$ for $24 \mathrm{~h}$ in a conventional air oven (model PP 22 US, Genlab, England), milled into fine powder using a manual grinder, packaged in air-tight plastic containers, labeled and stored at $4^{\circ} \mathrm{C}$ for analysis.

\subsection{Methods of Analysis}

The crude protein, fat, ash and crude fibre were determined following the methods described in AOAC [15]. Carbohydrate was calculated by difference [16]. Amino acid profile of the samples was determined by the method described by Spackman et al. [17]. The samples for amino acid determination were dried to constant weight, defatted, hydrolyzed, evaporated in a rotary evaporator (Labratorums Technic AG, Model CH - 9230) and loaded into a Technicon Multi-Sample Amino Acid Analyzer (TSM) (Technicon TSM-1, model DNA 0209, Dublin, Republic of Ireland). Essential amino acid scores were computed with respect to the FAO/WHO reference amino acid pattern [18]. The minerals ( $\mathrm{Ca}, \mathrm{K}, \mathrm{Na}, \mathrm{Mg}, \mathrm{Fe}$ and $\mathrm{Zn}$ ) were determined using atomic absorption spectrophotometer (UNICAM, Model 939, $\mathrm{UK})$ as described in AOAC [15].

\subsection{Statistical Analysis}

Data were presented as means \pm SD (Standard deviation) of triplicate determinations. Statistical analysis was performed by using SPSS version 18 statistical package (SPSS, Inc. USA). Analysis of variance (ANOVA) was done to determine significant difference at $p<0.05$. Means were separated using Duncan's Multiple Range Test (DMRT).

\section{Results and Discussion}

\subsection{Proximate Composition}

The proximate composition of powders prepared from edible parts of Tympanotonus fuscatus, Pachymelania aurita and Thais coronata is presented on Table 1 . The result showed that the proximate composition varied among the three gastropod species studied. This variation could be attributed to a number of factors including differences in species, feeding regime and many other physical and environmental conditions [7, 19]. Nurnadia et al. [20] stated that proximate composition of mollusc varied not only within species but also between species. Similar variations in the proximate composition of edible parts of different species of gastropods have been reported $[9,13,14,21]$. 
Protein was the major organic component of the powders made from the three investigated gastropod species. Thais coronata power had the highest protein content of $58.45 \%$ and showed a significant difference $(\mathrm{p}<0.05)$ from the other two samples. Tympanotonus fuscatus powder had the least protein content (46.51\%). This value was within the range of $40.27-47.80 \%$ reported by Adebayo-Tayo et al. [9], but lower than the value $(68.46 \%)$ reported by Ehigiator and Oterai [22] for T. fuscatus meat.

Table 1. Proximate composition of T. fuscatus, P. aurita and T. coronata meat powder (dry matter basis).

\begin{tabular}{llll}
\hline Parameters & $\begin{array}{l}\text { Tympanotonus } \\
\text { fuscatus }\end{array}$ & $\begin{array}{l}\text { Pachymelania } \\
\text { aurita }\end{array}$ & Thais coronata \\
\hline Crude protein (\%) & $46.51^{\mathrm{c}} \pm 0.10$ & $51.30^{\mathrm{b}} \pm 0.06$ & $58.45^{\mathrm{a}} \pm 0.21$ \\
Fat (\%) & $3.11^{\mathrm{a}} \pm 0.05$ & $2.94^{\mathrm{a}} \pm 0.11$ & $3.19^{\mathrm{a}} \pm 0.04$ \\
Ash (\%) & $12.80^{\mathrm{a}} \pm 0.02$ & $10.26^{\mathrm{b}} \pm 0.00$ & $13.85^{\mathrm{a}} \pm 0.06$ \\
Crude fibre (\%) & $0.41^{\mathrm{a}} \pm 0.13$ & $0.46^{\mathrm{a}} \pm 0.21$ & $0.38^{\mathrm{a}} \pm 0.10$ \\
Carbohydrate (\%) & $36.17^{\mathrm{a}} \pm 0.09$ & $35.04^{\mathrm{a}} \pm 0.05$ & $25.13^{\mathrm{b}} \pm 0.03$ \\
Caloric value & $358.71^{\mathrm{b}} \pm 0.06$ & $371.82^{\mathrm{a}} \pm 0.08$ & $363.03^{\mathrm{b}} \pm 0.11$ \\
\hline (kcal/100g) & & \\
\hline
\end{tabular}

Values are means \pm SD (standard deviation) of triplicate determinations. Means on the same row with different superscripts are significantly different at $\mathrm{p}<0.05$.

The protein content of $51.30 \%$ recorded for $P$. aurita powder in the present study was higher than the values of $49.54 \%$ and $48.62 \%$ reported by Adebayo-Tayo et al. [9] and Job and Ekanem [13] for P. aurita meat. Proteins are the source of dietary amino acids and are used for growth and maintenance of living system [1]. The high protein content in the three samples suggests that the powders could be used to fortify carbohydrate based diets as a step towards alleviating the problem of protein - energy malnutrition still prevalent in our communities.

Powders produced from the three gastropod species recorded low fat contents which were not significantly different $(p>0.05)$ from each other. The fat content in the powders ranged from $2.94 \%$ to $3.19 \%$ with $T$. coronata meat powder having the highest value and $P$. aurita meat powder having the least value. The fat contents obtained in the present study were lower than $6.31 \%$ and $6.73 \%$ reported by Job and Ekanem [13] for T. fuscatus and P. aurita meat respectively as well as $7.68 \%$ reported by Ehigiator and Oterai [22] for T. fuscatus meat. The values were however higher than $1.16 \%$ and $1.32 \%$ reported by Davies and Jamabo [23] for T. fuscatus and T. coronata meat respectively. The low fat content in the samples suggests that the powders could be incorporated in foods for hypertensive individuals and those that have fat related diseases like arteriosclerosis.

The ash content in the samples ranged from $10.26 \%$ for $P$. aurita meat powder to $13.85 \%$ for $T$. coronata meat powder. The value for T. fuscatus meat powder was $12.80 \%$. Similar variations in the ash content in edible parts of different gastropod species have been reported [19, 20, 23]. The ash content values obtained in the present study were higher than $10.16 \%$ reported by Ehigiator and Oterai [22] for T. fuscatus; $4.72-4.80 \%$ reported by Adebayo-Tayo et al. [9] for $P$. aurita meat and $9.56 \%$ reported by Ogungbenle and Omowole [24] for T. fuscatus. The obtained ash contents were however close to the range of $11.26-12.44 \%$ reported by Adebayo-Tayo et al. [25] for fresh water snails from Niger Delta creek in Nigeria. The ash content of a food material gives an idea about the inorganic content of the sample from where the mineral elements could be derived. The high ash content in the meat powders is therefore an indication that they contain high mineral elements.

All the powder samples had very low crude fibre contents which ranged from $0.38 \%$ for $T$. coronata meat powder to $0.46 \%$ for $P$. aurita meat powder. Similar variations in the crude fibre content of edible parts of different species of shellfish have been reported by other authors [20, 25, 26]. The crude fibre content values obtained in the present study were lower than $0.49 \%$ and $0.51 \%$ reported by Job and Ekanem [13] and Ehigiator and Oterai [22] for crude fibre contents of edible parts of $P$. aurita and $T$. fuscatus respectively. The low level of crude fibre in the powders will make them suitable for use in complementary foods. The carbohydrate content in $T$. coronata meat powder $(25.15 \%)$ was significantly $(\mathrm{p}<0.05)$ lower than the values in the powders of the other two species. The percentage carbohydrate contents in T. fuscatus and $P$. aurita meat powders were $36.17 \%$ and $35.04 \%$ respective but the values were not significantly $(p>0.05)$ different from each other. The carbohydrate contents recorded in the present study were lower than $47.64 \%$ and $51.49 \%$ reported by Adebayo-Tayo et al. [9] and Job and Ekanem [13] for T. fuscatus and P. aurita meat respectively. The caloric value of the samples ranged from $358.71 \mathrm{kcal} / 100 \mathrm{~g}$ to $371.82 \mathrm{kcal} / 100 \mathrm{~g}$ with $T$. fuscatus meat powder having the least value while $P$. aurita meat powder had the highest value.

\subsection{Amino Acid Composition}

Amino acids are component subunits of protein. According to Sarma et al. [27], the amino acid is one of the most important nutritional qualities of proteins. They play a vital role both as building blocks of proteins and as intermediates in metabolism [5]. The amino acid composition of powders prepared from edible parts of T. fuscatus, $P$. aurita and $T$. coronata is presented on Table 2 . The result showed that a total of eighteen (18) amino acids were identified from the powders of the three gastropod species. It was observed that the individual amino acids, total amino acids and total essential amino acids varied between the three species. Similar variations in the amino acid composition of some mollusc species have been reported by other authors [5, 28]. Leiwakabessy and Lewerissa [28] reported that variation in the amount of amino acid in marine organisms is not only occurred in different species but also in within species. According to Wesselinova [29], the amino acid content of marine organisms varies depending on a variety of factors such as the species, size, seasonal conditions and geographical location.

The total amino acid contents of T. fuscatus, $P$. aurita and T. coronata meat powders were $77.76 \mathrm{~g} / 100 \mathrm{~g}$ protein, 
$79.02 \mathrm{~g} / 100 \mathrm{~g}$ protein and $83.53 \mathrm{~g} / 100 \mathrm{~g}$ protein respectively. For all the species, glutamic acid was the highest contributor to the total amino acid.

Table 2. Amino acid composition of T. fuscatus, P. aurita and T. coronata meat powder ( $\mathrm{g} / 100 \mathrm{~g}$ protein).

\begin{tabular}{llll}
\hline Amono Acid & $\begin{array}{l}\text { Tympanotonus } \\
\text { fuscatus }\end{array}$ & $\begin{array}{l}\text { Pachymelania } \\
\text { aurita }\end{array}$ & $\begin{array}{l}\text { Thais } \\
\text { coronata }\end{array}$ \\
\hline Leucine & $7.24^{\mathrm{b}} \pm 0.04$ & $8.70^{\mathrm{a}} \pm 0.02$ & $9.22^{\mathrm{a}} \pm 0.05$ \\
Lysine & $4.64^{\mathrm{b}} \pm 0.01$ & $5.19^{\mathrm{a}} \pm 0.06$ & $5.64^{\mathrm{a}} \pm 0.03$ \\
Isoleucine & $3.80^{\mathrm{a}} \pm 0.05$ & $3.41^{\mathrm{a}} \pm 0.05$ & $3.60^{\mathrm{a}} \pm 0.10$ \\
Phenylalanine & $3.46^{\mathrm{b}} \pm 0.11$ & $4.08^{\mathrm{a}} \pm 0.01$ & $4.43^{\mathrm{a}} \pm 0.06$ \\
Tryptophan & $0.97^{\mathrm{b}} \pm 0.02$ & $0.99^{\mathrm{b}} \pm 0.02$ & $1.36^{\mathrm{a}} \pm 0.11$ \\
Valine & $3.80^{\mathrm{a}} \pm 0.05$ & $3.65^{\mathrm{b}} \pm 0.04$ & $4.09^{\mathrm{a}} \pm 0.02$ \\
Methionine & $1.44^{\mathrm{a}} \pm 0.03$ & $1.60^{\mathrm{a}} \pm 0.04$ & $1.84^{\mathrm{a}} \pm 0.10$ \\
Cystine & $1.15^{\mathrm{a}} \pm 0.10$ & $1.02^{\mathrm{a}} \pm 0.03$ & $0.91^{\mathrm{a}} \pm 0.06$ \\
Threonine & $3.38^{\mathrm{b}} \pm 0.02$ & $4.05^{\mathrm{a}} \pm 0.10$ & $3.24^{\mathrm{b}} \pm 0.04$ \\
Tyrosine & $3.09^{\mathrm{a}} \pm 0.04$ & $3.09^{\mathrm{a}} \pm 0.08$ & $3.44^{\mathrm{a}} \pm 0.05$ \\
Proline & $3.96 \pm 0.02$ & $3.45^{\mathrm{a}} \pm 0.00$ & $3.96^{\mathrm{a}} \pm 0.12$ \\
Arginine & $6.19^{\mathrm{a}} \pm 0.03$ & $5.95^{\mathrm{a}} \pm 0.03$ & $6.02^{\mathrm{a}} \pm 0.03$ \\
Histidine & $2.55^{\mathrm{a}} \pm 0.01$ & $2.46^{\mathrm{a}} \pm 0.05$ & $2.33^{\mathrm{a}} \pm 0.02$ \\
Alanine & $3.87^{\mathrm{b}} \pm 0.06$ & $4.09^{\mathrm{a}} \pm 0.04$ & $4.28^{\mathrm{a}} \pm 0.06$ \\
Glutamic acid & $12.11^{\mathrm{a}} \pm 0.03$ & $11.96^{\mathrm{b}} \pm 0.06$ & $13.32^{\mathrm{a}} \pm 0.10$ \\
Glycine & $4.01^{\mathrm{a}} \pm 0.02$ & $3.94^{\mathrm{a}} \pm 0.02$ & $4.01^{\mathrm{a}} \pm 0.04$ \\
Serine & $3.54^{\mathrm{a}} \pm 0.04$ & $3.24^{\mathrm{a}} \pm 0.01$ & $3.59^{\mathrm{a}} \pm 0.00$ \\
Aspartic acid & $8.56^{\mathrm{a}} \pm 0.03$ & $8.15^{\mathrm{a}} \pm 0.11$ & $8.25^{\mathrm{a}} \pm 0.02$ \\
TAA & $77.76^{\mathrm{b}} \pm 0.02$ & $79.02^{\mathrm{b}} \pm 0.08$ & $83.53^{\mathrm{a}} \pm 0.4$ \\
TEAA & $32.97^{\mathrm{c}} \pm 0.04$ & $35.78^{\mathrm{b}} \pm 0.02$ & $37.77^{\mathrm{a}} \pm 0.03$ \\
TEAA/TAA $(\%)$ & 42.40 & 45.28 & 45.22 \\
TSAA & 2.59 & $2.62^{2}$ & 2.75 \\
\hline
\end{tabular}

Values are means \pm SD (standard deviation) of triplicate determinations. Means on the same row with different superscripts are significantly different at $\mathrm{p}<0.05$. TAA - total amino acid; TEAA - total essential amino acid; TSAA $=$ total sulphur amino acid.

Similar observation had been reported by other authors $[22$, 24]. The total essential amino acid for $T$. fuscatus, $P$. aurita and $T$. coronata meat powder were $32.97 \mathrm{~g} / 100 \mathrm{~g}$ protein, $35.78 \mathrm{~g} / 100 \mathrm{~g}$ protein and $37.77 \mathrm{~g} / 100 \mathrm{~g}$ protein respectively, with leucine as the major contributor for all the samples. For $T$ fuscatus and $P$. aurita powders, tryptophan was the least contributor to the essential amino acid whereas for $T$. coronata powder, cystine was the least contributor to the essential amino acid. All amino acids in foods have different role that helps the body to grow and function normally. Essential amino acids are however indispensable as they are not synthesized in the body and must be supplied in adequate amount through diets. The essential amino acids are required for nutrition, promotion of normal growth and maintenance of nitrogen balance while the non-essential amino acids are physiologically important to take part in the general metabolic reactions [30]. The absences of any of the essential amino acids in the diet impair the ability of tissue to grow, be repaired or maintained [31].

Comparison between the essential amino acid composition of the present study and the reference values of FAO/WHO/UNU [18] showed that most of the essential amino acids would meet the recommended range of amino acid required for children aged $2-5$ years and adults. Amino acid scores as presented on Table 3 revealed that majority of the scores were above $100 \%$ except for lysine that the scores ranged between $80.00 \%$ and $97 \%$; tryptophan was $88.18 \%$ for $T$. fuscatus and $90.00 \%$ for $P$. aurita while threonine was $95.29 \%$ for $T$. coronata and $99.41 \%$ for $T$. fuscatus powders. The result of the present study clearly showed that the proteins in $T$. fuscatus, $P$. aurita and $T$. coronata meat powders are of high quality with balanced essential amino acids and could be used as food fortifiers.

Table 3. Essential amino acid score of periwinkle and Rock snail meat powder protein (\%).

\begin{tabular}{lllll}
\hline Amono Acid & Tympanotonus fuscatus & Pachymelania aurita & Thais coronate & ${ }^{*}$ FAO/WHO (1985) Reference Value (g/100g protein) \\
\hline Leucine & 109.53 & 131.62 & 139.49 & 6.61 \\
Lysine & 80.00 & 89.48 & 97.24 & 5.80 \\
Isoleucine & 135.71 & 121.79 & 128.57 & 2.80 \\
Phen. + Tyro. & 103.97 & 113.81 & 124.92 & 6.30 \\
Tryptophan & 88.18 & 90.00 & 123.64 & 1.10 \\
Valine & 108.57 & 104.29 & 116.86 & 3.50 \\
Met. + Cyst. & 103.60 & 104.80 & 110.00 & 2.50 \\
Threonine & 99.41 & 119.12 & 95.29 & 3.40 \\
\hline
\end{tabular}

* Reference amino acid pattern of pre-school children $(2-5$ years $)(F A O / W H O / U N U, 1985)$. Phen. $=$ Phenylalanine; tyro = tyrosine; Met = Methionine; Cyst. $=$ cystine.

\subsection{Minerals}

Minerals are essential nutrients that are needed to facilitate proper functioning of certain organs in the body. The mean concentrations of mineral elements $(\mathrm{Ca}, \mathrm{K}, \mathrm{Na}, \mathrm{Mg}, \mathrm{Fe}$ and $\mathrm{Zn}$ ) in Tympanotonus fuscatus, Pachymelania aurita and Thais coronata meat powders are summarized on Table 4. The result showed variation in all the mineral elements determined between the species. It has been reported that variation in mineral composition of marine foods could be due to the differences of species, area of catch, and many physical and environmental conditions [20, 32].

Overall, magnesium was the most abundant mineral present in the powders from the three gastropod species analyzed. This observation was in agreement with the report by Nurnadia et al. [20] for marine fish and shellfish from the west coast of Peninsular, Malaysia. Magnesium value was highest $(208.05 \mathrm{mg} / 100 \mathrm{~g})$ in the powder prepared from $T$. coronata meat and was significantly $(p<0.05)$ different from the values in the powders from the other two species. 
Table 4. Mineral content in T. fuscatus, $P$. aurita and T. coronata meat powder (mg/100g).

\begin{tabular}{llll}
\hline Parameters & $\begin{array}{l}\text { Tympanotonus } \\
\text { fuscatus }\end{array}$ & $\begin{array}{l}\text { Pachymelania } \\
\text { aurita }\end{array}$ & $\begin{array}{l}\text { Thais } \\
\text { coronata }\end{array}$ \\
\hline $\mathrm{Ca}$ & $41.38^{\mathrm{c}} \pm 0.15$ & $56.74^{\mathrm{b}} \pm 0.09$ & $79.02^{\mathrm{a}} \pm 0.05$ \\
$\mathrm{~K}$ & $29.51^{\mathrm{a}} \pm 0.06$ & $33.62^{\mathrm{b}} \pm 0.12$ & $42.10^{\mathrm{a}} \pm 0.10$ \\
$\mathrm{Na}$ & $74.09^{\mathrm{b}} \pm 0.12$ & $81.16^{\mathrm{a}} \pm 0.08$ & $68.24^{\mathrm{a}} \pm 0.11$ \\
$\mathrm{Mg}$ & $140.00^{\mathrm{c}} \pm 0.14$ & $155.21^{\mathrm{b}} \pm 0.10$ & $208.05^{\mathrm{a}} \pm 0.13$ \\
$\mathrm{Fe}$ & $10.19^{\mathrm{a}} \pm 0.09$ & $9.05^{\mathrm{a}} \pm 0.20$ & $11.62^{\mathrm{b}} \pm 0.15$ \\
$\mathrm{Zn}$ & $3.08^{\mathrm{a}} \pm 0.04$ & $2.64^{\mathrm{a}} \pm 0.04$ & $2.91^{\mathrm{b}} \pm 0.06$ \\
\hline
\end{tabular}

Values are means \pm SD (standard deviation) of triplicate determinations. Means on the same row with different superscripts are significantly different at $\mathrm{p}<0.05$.

The least magnesium value $(140.00 \mathrm{mg} / 100 \mathrm{~g})$ was recorded for T fuscatus powder while the level in P. aurita powder was $155.21 \mathrm{mg} / 100 \mathrm{~g}$. Similar variations in the magnesium content of shellfish have been reported by other authors $[14,20]$. Magnesium is a mineral that affects the metabolism of calcium, sodium and potassium [33]. It is important for bone health; is needed as a cofactor for numerous reactions in the body and is also essential for nerve and muscle conductivity [33].

T. coronata powder had the highest concentration of calcium $(79.02 \mathrm{mg} / 100 \mathrm{~g})$ and potassium $(42.10 \mathrm{mg} / 100 \mathrm{~g})$ while $T$. fuscatus powder had the least concentration of calcium $(41.38 \mathrm{mg} / 100 \mathrm{~g})$ and potassium $(29.51 \mathrm{mg} / 100 \mathrm{~g})$. The calcium and potassium values in the three powders were significantly $(\mathrm{p}<0.05)$ different from each other. Calcium is important for developing and maintaining bones and teeth as well as supporting the healthy functioning of muscles, nerves and the heart [34]. Potassium is required in relatively large amount in the body because it functions as an important electrolyte in the nervous system, plays a role in osmoregulation and can help control blood pressure [33]. High amount of potassium, calcium and magnesium have been reported to reduce blood pressure in humans [35].

Sodium content in the samples ranged from $68.24 \mathrm{mg} / 100 \mathrm{~g}$ to $81.16 \mathrm{mg} / 100 \mathrm{~g}$, with powder from T. coronata having the least value while powder from $P$. aurita had the highest value. The values for sodium recorded in the present study were less than $96.64 \mathrm{mg} / 100 \mathrm{~g}$ and $112.60 \mathrm{mg} / 100 \mathrm{~g}$ reported by Kiinkabari et al. [14] for smooth and rough periwinkles respectively. The values were also lower than $90.00 \mathrm{mg} / 100 \mathrm{~g}$ reported by Ehigiator and Oterai [22] for T. fuscatus meat. Blood pressure and blood volume in the human body are under the regulation and control of sodium [33].

The iron content in the powders ranged from $9.05 \mathrm{mg} / 100 \mathrm{~g}$ in $P$. aurita meat powder to $11.62 \mathrm{mg} / 100 \mathrm{~g}$ in the $T$. coronata meat powder. This shows that periwinkle and rock snail meat are good sources of iron. The values for iron in the powders recorded in the present study were in close agreement with the values $(9.69 \mathrm{mg} / 100$ and $12.35 \mathrm{mg} / 100 \mathrm{~g})$ reported by Davies and Jamabo [23] for T. fuscatus and T. coronata meat respectively. The value were however lower than $12.73 \mathrm{mg} / 100 \mathrm{~g}$ and $12.75 \mathrm{mg} / 100$ reported by Job and Ekanem [13] for periwinkle species. Iron is an essential mineral in the heme molecule of hemoglobin, the component of the blood cell that carries oxygen in the blood stream. Adequate iron in the diet is essential to minimize the incidence of iron deficiency anaemia, which is considered a major public health problem, especially in young children. $T$. fuscatus meat powder had the highest zinc content $(3.08 \mathrm{mg} / 100 \mathrm{~g})$ while the least value $(2.64 \mathrm{mg} / 100 \mathrm{~g})$ was recorded for $P$. aurita meat powder. The values were however not significantly $(p>0.05)$ different from each other. The zinc values recorded in the present study were lower than $12.42 \mathrm{mg} / 100 \mathrm{~g}$ and $10.42 \mathrm{mg} / 100 \mathrm{~g}$ reported by Kiin-kabari et al. [14] for smooth and rough periwinkle meats respectively. Zinc is essential for the synthesis of DNA and RNA, proteins and insulin. It is also essential for proper functioning of immunity system and for activation of some enzymes [34].

\section{Conclusion}

The results of the study showed that the proximate composition, amino acid profile and mineral content of $T$. fuscatus, $P$. aurita and T. coronata meat powders varied among the species. Powders prepared from the three gastropod species had high protein content, low fat and fibre contents. Comparison between the essential amino acid composition and the reference values of $\mathrm{FAO} / \mathrm{WHO}$ showed that most of the essential amino acids would meet the recommended ranged for children aged $2-5$ years and adults. The high protein and low crude fibre contents in the powders will make them suitable for use in complementary foods. Also, the low fat content in the powders suggests that they could be incorporated in foods for hypertensive individuals and those that have fat related diseases. Successful application of these powders in food product formulation and product development will lead to increase utilization of these nutritious, cheap and readily available sources of meat protein.

\section{References}

[1] B. Sivasankar. Food Processing and Preservation. PHI Learning Private Limited, New Delhi. 2011. pp. 303-304.

[2] Food and Agriculture Organization of the United Nations/World Health Organization. Report on the Joint FAO/WHO Expert Consultations on the Risks and Benefits of Fish Consumption. FAO Fisheries and Aquaculture Report No. 978, 2010.

[3] R. Hosomi, M. Yoshida and K. Fukunaga. Seafood Consumption and component for Health. Global J. Health Sci. 4(3):72-86, 2012.

[4] S. Arularasan, P. S. Lyla, K. Kesavan and S. A. Khan. Recipes for the Mesogastropods - Strombus canavium. Adv. J. Food Sci. Technol. 2(1):31-35, 2009.

[5] A. Babu, V. Venkatesan and S. Rajagopal. Fatty acid and amino acid composition of the gastropods, Tonna dolium (Linnaeus, 1758) and Phalium glaacum (Linnaeus, 1758) from the Gulf of Mannar, South East Coast of India. Annals Food Sci. Technol. 12(1):159-163, 2011. 
[6] B. Ersoy and H. Sereflisan. The Proximate composition and fatty acid profile of edible parts of two freshwater mussels. Tukish J. Fisheries Aquatic Sci. 10:71-74, 2010.

[7] N. Periyasamy, M. Srinivasan, K. Devanathan and S. Balakrishnam. Nutritional value of gastropod, Babylonia spirata (Linnaeus, 1858) from Thazhanguda, Southeast Coast of India. Asian Pacific J. Trop. Biomed. S249-S252, 2011.

[8] W. F. Ponder and D. R. Lindberg. Phylogeny and evolution of the mollusca. University of California Press, Los Angeles, California, 2008. pp. 1-18.

[9] B. C. Adebayo-Tayo, A. A. Onilude, A. Ogunjobi and D. O. Adejoye. Bacteriological and Proximate analysis of periwinkle from two different creeks in Nigeria. World Appl. Sci. J. 1(2):87-91, 2006.

[10] J. K. Ideriah, S. A. Braide and A. O. Briggs. Distribution of lead and total hydrocarbon in tissue of periwinkle (Tympanotonus fuscatus and Pachymelinia) in the upper Bonny River, Nigeria. J. Appl. Sci. Environ. Manage. 10(2):145-150, 2005.

[11] W. B. Dambo. Tolerance of periwinkle Pachymelania aurita and Tympanotonus fuscatus to refined oil. Environ. Pollut. 99:293-296, 1993.

[12] I. U. Ebong, N. C. Osuchukwu and E. U. Ebong. Liver enzymes and hematological effect of sub-chronic periwinkle (Pachymelania aurita) and rock snail (Thais coronata) consumption in anaemic albino rats. J. Med. Sci. 14(4):174178, 2014.

[13] B. E. Job and A. P. Ekanem. Nutritional status of two periwinkle species from a tropical creek in Nigeria. Afr. J. Environ. Pollut. Health. 8(1):41-44, 2010.

[14] D. B. Kiin-kabari, A. D. hart and P. T. Nyeche. Nutritional composition of selected shellfish consumed in River State, Nigeria. Amer. J. Food Nutr. 5(4):142-146, 2017.

[15] AOAC, Official Methods of Analysis (18 $18^{\text {th }}$ end.). Association of Official Analytical Chemists, Washington D. C., USA, 2005.

[16] A. I. Ihekoronye and P. O. Ngoddy. Integrated Food Science and Technology for the Tropics. MacMillan Edu. Publishers, London. 1985, pp. 283-285.

[17] D. H. Spackman, E. H. Stein and S. Moore. Automatic recording apparatus for use in chromatography of amino acids. Analy. Chem.. 30:1191-1197, 1958.

[18] FAO/WHO/UNU. Energy and protein requirements. Report of a Joint FAO/WHO/UNU Expert Consultations. World Health Organization Technical Report Series 724, Geneva, WHO. 1985.

[19] M. Y. Celik, S. T. Culha, M. Culha, H. Yildiz, S. Acarli, I. Celik and P. Celik. Comparative study of biochemical composition of some marine edible molluscs at Canakkale Coast, Turkey. Indian J. Geo-marine Sci. 43(4):601-606, 2014.

[20] A. A. Nurnadia, A. Azina and I. Amin. Proximate composion and energetic value of selected marine fish and shellfish from West coast of Peninsular Malaysia. Int. Food Res. J. 18:137148, 2011.
[21] M. S. Margret, M. Santhiya, M. T. Mary and M. Jansi. Comparative study on the biochemical composition of four gastropods along the Kanyakumari Coast. Word J. Fishery and Marine Sci. 5(6):637-640, 2013.

[22] F. A. R. Ehigiator and E. A. Oterai. Chemical composition and amino acid profile of a Caridean prawn (Macrobrachium vollenhovenii) from Ovia River and Tropical periwinkle (Tympanotonus fuscatus) from Benin River, Edo State, Nigeria. Int. J. Recent Res. Appl. Studies. 11(1):162-167, 2012.

[23] I. C. Davies and N. A. Jamabo. Proximate composition of edible parts of shellfish from Okpoka Creeks in River State, Nigeria. Int. J. Life Sci. Res. 4(2):247-252, 2016.

[24] H. N. Ogungbenle and B. M. Omowole. Chemical, functional and amino acid composition of periwinkle (Tympanotonus fuscatus var radula) meat. Int. J. Pharm. Sci. Res. 13(2):128132, 2012.

[25] B. C. Adebayo-Tayo, A. A. Onilude and F. I. Etuk. Studies on microbiological, proximate, mineral and heavy metal composition of fresh water snails from Niger Delta Creek in Nigeria. Assumption Uni. J. Technol. 14(4):290-298, 2011.

[26] R. Ab Lah, J. Smith, D. Savin, A. Dowell, D. Bucher and K. Benkendorff. Investigation of nutritional properties of three species of marine turban snails for human consumption. Food Sci. Nutr. 5(1):14-30, 2017.

[27] D. Sarma, P. D. Das, P. Das, H. C. S. Bisht, M. S. Akhtar and A. Ciji. Fatty acid, amino acid and mineral composition of rainbow trout (Oncorhynchus mykiss) of Indian Himalaya. Indian J. Animal Res. 49(3):399-404, 2015.

[28] J. Leiwakabessy and S. Lewerissa. Amino acid profile of Strombus luhuanus and Lambis lambis from Waisarisa and Suli water, Maluku Province, Indonesia. AACL - Bioflux. 10(5):1174-1179, 2017.

[29] D. Wesselinova. Amino acid composition of fish meat after different frozen storage period. J. Aquatic Food Prod. Technol. 9:41-48, 2000.

[30] D. Jayaprabha. Amino acid and fatty acid profile of the marine gastropod Turbo brunneu (L., 1758) along the Gulf of Mannar Region of Thoothukudi. Int. J. Recent Innovat. Trends in Comput. Comm. 4(5):284-287, 2016.

[31] J. R. Hoffman and M. J. Falvo. Protein - which is the best? J. Sport Sci. Med. 3:118-130, 2004.

[32] C. Alasalvar, K. D. A. Taylor, E. Zubcov, F. Shahidi and M. Alexis. Differentiation of cultured and wild sea bass (Dicentrarchus labrax): total lipid content, fatty acid and trace element composition. Food Chem. 79(3):145-150, 2002.

[33] M. B. Grosvernor and L. A. Smolin. Nutrition: From science to life. Harcourt College Publishers, New York. 2002, pp. 404469.

[34] T. T. Lilly, J. K. Immaculate and P. Jamila. Macro and micronutrients of selected marine fishes in Tuticorin, South East Coast of India. Int. Food Res. J. 24(1):191-201, 2017.

[35] G. S. Ranhotra, J. A. Gelroroth, S. O. Leinen, M. A. Vrnas and K. J. Lorenz. Nutritional profile of some edible plants from Mexico. J. Food comp. anal. 11:298-304, 1998. 